\title{
A New Spectrophotometric Method for Determination of Iron in Herbs, Spices and Beans with 2,6-Diacetylprydine Dioxime and 2-Acetylpyridine Monoxime
}

\author{
Z.R. Komy, E.A. Abu-Gharib and A. Desoky \\ Department of Chemistry, Faculty of Science, South Valley University, Shag Egypt
}

\begin{abstract}
The reaction of iron (II) with 2, 6-diacetylprydine dioxime $\left(\mathrm{H}_{2} \mathrm{dapd}\right)$ and 2-acetylprydine monoxime (Hapm) in $10 \%$ and $60 \% \mathrm{v} / \mathrm{v}$ ethanol-water solution at $\mathrm{pH} 2.5$ and 7.5 , respectively, were studied using direct and first derivative spectrophotometry. $\mathrm{Fe}$ (III) is reduced by $\mathrm{H}_{2}$ dapd and gives iron (II) complex. A simple, rapid, selective and sensitive method for the determination of Fe (II), Fe (III) and a mixture of them with the $\mathrm{H}_{2}$ dapd reagent in acid water-ethanol medium after the solution attained to stand periods of $30 \mathrm{sec}, 4 \mathrm{hr}$ and $4 \mathrm{hr}$, respectively, are proposed. Hapm also reacts with $\mathrm{Fe}$ (II) to form $\left[\mathrm{Fe}(\mathrm{Hapm})_{3}\right]^{2+}$ complex with less selectivity and sensitivity than $\mathrm{H}_{2} \mathrm{dapm}$ reagent. Calibration graph with $\left[\mathrm{Fe}\left(\mathrm{H}_{2} \mathrm{dapd}\right)_{2}\right]^{2+}$ is linear over the range $0.28 \mu \mathrm{g} \mathrm{mL} \mathrm{L}^{-1}$ with an apparent molar absorptivity of $8.481 \times 10^{3} \mathrm{~L} \mathrm{~mol}^{-1} \mathrm{~cm}^{-1}$ at $\lambda_{\mathrm{m}} 428 \mathrm{~nm}$. Linear dynamic ranges are 0.01-11.0 and 0.07$11.0 \mu \mathrm{g} \mathrm{mL} \mathrm{g}^{-1}$ iron (II) as $\left[\mathrm{Fe}\left(\mathrm{H}_{2} \mathrm{dapd}\right)_{2}\right]^{2+}$ complex for direct and derivative modes, respectively. The analytical sensitivity is $4.44 \times 10^{-3} \mu \mathrm{g} \mathrm{mL} \mathrm{m}^{-1}$ for direct and $9.15 \times 10^{-5} \mu \mathrm{g} \mathrm{mL^{-1 }}$ for derivative spectrophotometry with $\left[\mathrm{Fe}\left(\mathrm{H}_{2} \mathrm{dapd}\right)_{2}\right]^{2+}$ complex. First derivative method enhances the sensitivity of the $\left.\mathrm{Fe}\left(\mathrm{H}_{2} \mathrm{dapd}\right)_{2}\right]^{2+}$ more than direct one with two folds for $\mathrm{Ni}^{2+}, \mathrm{Co}^{2+}, \mathrm{Cu}^{2+}$ and $\mathrm{Cr}^{3+}$. A linear equation was derived from iron (II) determining as $\left.\mathrm{Fe}\left(\mathrm{H}_{2} \mathrm{dapd}\right)_{2}\right]^{2+}$ in the presence of synthetic solution containing $\mathrm{Ni}^{2+}, \mathrm{Co}^{2+}, \mathrm{Cu}^{2+}$ and $\mathrm{Cr}^{3+}$. The use of $\mathrm{H}_{2}$ dapd reagent for the determination of total iron spectrophotometerically in foodstuffs, herbs, spices (rocks) after wet ashing (wet digestion) in the absence of reducing agent is compared with that employing AAS.
\end{abstract}

Key words: Iron, spectrophotometry, iron(ii)-2, 6-diacetylprydine dioxime complex, spices, herbs, beans, rocks

\section{INTRODUCTION}

Recently, there has been a growing concern about the role of iron (II) in biochemical and environmental systems, regarding man, animals and plants. Iron (II) lead to many diseases such as giddiness, diarrhea and cardiac collapse-conditions found amongst people, to damage of the gastrointestinal tract and liver ${ }^{[1]}$. These diseases can lead to a problem in iron absorption and in turn iron toxicity.

Because of the ever-increasing interest in the determination of different oxidation state of iron in outdoor samples, there is a need for the development of more sensitive and selective analytical methods. The common availability and low cost of instrumentation, the simplicity of procedures, the accuracy and selectivity of the technique make spectrophotometric method advantage for the determination of iron. Flow Injection Analysis (FIA), intensively a developed over the past 20 years, offers several valuable advantages for speciation of iron $^{[2]}$, where individual signals were obtained for $\mathrm{Fe}$ (II) and $\mathrm{Fe}$ (III). However, the determination of iron with the FIA is expensive and with complicated experimental conditions that makes it not an alternative for routine analysis.
Much attention was given for measuring iron (II) with organic reagents spectrophotometerically in an acidic medium and first derivative, which not only offers convenient solutions to a number of analytical problems such as avoiding extraction process, resolution of component systems and matrix background, but also enhances the selectivity and sensitivity of the method. A few of them used N-mchlorophenyl-p-methoxy-benzohydroxaimic acid ${ }^{[3]}$ in faintly acidic medium after extraction iron complex with trioctylamine in toluene and 2 [2 (6methylbenzothiazolyl) azo] -5- diethylaminobenzoic $\mathrm{acid}^{[4]}$ after reduction iron (III) samples with ascorbic acid in acetate buffer $(\mathrm{pH}=5$. 8). Whereas, 5-[(3,5dibromo-2-pyridylazo)] -2,4-[diamino-toluene [3, -5DBPADAT] ${ }^{[5]}$ or 2,2'-bipyridyl reagents were used in acetate buffer at $\mathrm{pH}=4.7$ or $4.5^{[6]}$. Finally, sulfosalicylic acid ${ }^{[7]}$ in the presence of hexamine/HCl buffer solution $(\mathrm{pH}=5.8)$ was used.

5,5-dimethyl-1,2,3-cyclohexanetrione 1,2-dioxime3-thiosemicarbazone (DCDT) legend has been proposed as a spectrophotometric reagent for determining iron (II) in wines, food, minerals, commercial acids and fruit juices ${ }^{[8-10]}$. DCDT reacts in a strong acidic medium with $\mathrm{Fe}$ (II) and Fe (III) to form a violet iron (II)-complex. The optimum acidity range in 
$\mathrm{HCl}$ medium, complex formation is ranged from 0.1 to $7.5 \mathrm{~mol} \mathrm{~L}^{-1}$.

The iron reaction with DCDT is unusual due to the high acidity of the medium. In addition, results showed that molar absorptivity, Beer's low and detection limit were $8.9 \times 10^{3} \mathrm{~L} \mathrm{~mol}^{-1} \mathrm{~cm}^{-1}, 0.7-5.0 \mu \mathrm{g} \mathrm{mL}^{-1}$ and 0.05 $\mu \mathrm{g} \mathrm{mL} L^{-1}$ respectively. Results also showed that $\mathrm{Co}^{2+}$, $\mathrm{Ni}^{2+}, \mathrm{Cr}^{3+}$ and $\mathrm{Cu}^{2+}$ foreign ions in synthetic iron (II) solutions could be tolerated to 1.0, 5.0, 25.0 and 50.0 folds, respectively. Whereas after extracting iron into amyl alcohol the tolerance limit of $\mathrm{Co}^{2+}$ and $\mathrm{Cr}^{3+}$ were $5.0 \times 10^{-3}$ and $1.5 \times 10^{-2} \mu \mathrm{g} \mathrm{mL}^{-1}$, respectively.

Considering the relative stabilities and specific character of the axioms $(=\mathrm{N}-\mathrm{OH})$ complex of iron (II), 2,6-diacetylprydine dioxin $\left(\mathrm{H}_{2} \mathrm{dapd}\right)$ and 2acetylpyridine monoxide (Hapm) had much attention for the spectrophotometric kinetic studies ${ }^{[11-12]}$. Previous studies indicated that oximate anions were characterized with strong $\alpha$-nucleophilies ${ }^{[13]}$. Finally, $\mathrm{H}_{2}$ dapd possesses structural features in common with DCDT organic reagents. Based on the preliminary studies, $\mathrm{H}_{2}$ dapd and Hapm oxen are chosen as analytical reagents for iron (II) determination.

Recently, spices and herbs have gained an important role in agronomy production and pharmacy because of their increased needs as a raw material for flavorings beverage, food metabolites and medicinal components. A Vicia faba bean is considered to be one the most popular food in Egypt. Generally, direct determination of iron in herb, spice and bean samples is difficult due to high amounts of protein, amino acids, alkaloids, cellulose, starch, volatile and fixed oil and pigments in the extracts ${ }^{[14]}$, which caused a serious interference. Therefore, the iron determination is a requisite routine plant control analysis. Procedures usually used wet ashing in the preparation of the solutions for analysis ${ }^{[15]}$. Most organic matter in the extracts was destroyed by this process.

In this work, the analytical properties of $\mathrm{H}_{2}$ dapd or Hapm with iron (II) in acid or faintly alkaline medium are examined Spectro photo metrically. Comparison between direct and first derivative spectral methods has been established. The ability to measure trace amounts of $\mathrm{Fe}$ (III) and a mixture of $\mathrm{Fe}$ (II) and $\mathrm{Fe}$ (III) with $\mathrm{H}_{2}$ dapd is also exploited with the aim of $\mathrm{H}_{2}$ dapd that could reduce the $\mathrm{Fe}$ (III) to $\mathrm{Fe}$ (II). This work is considered as an attempt to develop a new, rapid and sensitive method to determine two different oxidation states of iron individually and in a binary mixture. $\mathrm{H}_{2}$ dapd organic reagent is applied for the determination of total iron as Fe (II) -complex in foodstuffs, herbs, spices and rocks.

\section{MATERIALS AND METHODS}

A Jasco V-530E Spectrophotometer with $1.0 \mathrm{~cm}$ quartz cells, a Buck Scientific Model 210 VGP Atomic Absorption Spectrophotometer (AAS), Shimadzu
FTIR-8101 Spectrophotometer, Perkin-Elmer 240C Elemental Analyzer and an Orion $\mathrm{pH}$ electrode fitted with a combined glass electrode were used. Milliporewater purification system was used.

Preparation of $\mathbf{H}_{2}$ dapd and Hapm Reagents: The $\mathrm{H}_{2}$ dapd or Hapm reagents were prepared from 2,6diacetylpyridine or 2-diacetylpyridine via the modified procedure $^{[16]}$. Briefly, into a $250 \mathrm{~mL}$ flask $4.1 \mathrm{~g}$ of 2,6 diacetylpyridine or $20 \mathrm{mmol}$ of 2-diacetylpyridine were mixed with 4.6 or $2.5 \mathrm{~g}$ of hydroxylamine hydrochloride and 4.8 or $2.4 \mathrm{~g}$ of barium carbonate, respectively, in $100 \mathrm{~mL}$ ethanol. The warmed mixture was stirred on a heating-stirrer and then refluxed for 5 hr. After filtration, the filtrate was left to stand overnight. The $\mathrm{H}_{2}$ dapd and Hapm oxime compound was re-crystallized from ethanol and dried.

Chemicals and Reagents: All entire reagents and solvents used were from BDH chemical grade except where indicated. 2,6-diacetylpyridine and 2-diacetylpyridine were obtained from Aldrich. $\mathrm{HCl}$ and $\mathrm{HNO}_{3}$ were ultrapur acids (Merck). A stock solution of 1.0 $\left(10^{-2} \mathrm{M} \mathrm{H}_{2}\right.$ dapd and Hapm reagents were prepared by dissolving reagent in ethanol. Stock solutions containing $1.0 \times 10^{-3} \mathrm{M}$ iron(II) and iron(III) (Merck) were prepared by dissolving an accurately weighed amounts of ferrous and ferric ammonium sulphate in $0.05 \mathrm{M} \mathrm{H}_{2} \mathrm{SO}_{4}$ and standardized titrimetrically with a standard $\mathrm{K}_{2} \mathrm{Cr}_{2} \mathrm{O}_{7}$ solution (daily) and gravimetrically by weighing as $\mathrm{F}_{2} \mathrm{O}_{3}$, respectively. Working solutions were prepared by appropriate dilution with ultrapure water. Air must be removed from all solutions by purging with free oxygen-nitrogen prior to the experiments and all additions of reagents must be carried out. All glassware was cleaned as the procedure described elsewhere ${ }^{[17]}$.

Calibration Plot: Under the optimum conditions, a linear calibration graph was obtained up to 11.0 and $16.0 \mu \mathrm{g} \mathrm{mL}^{-1}$ of iron (II) with $\mathrm{H}_{2}$ dapd and Hapm reagents, respectively. A plot showed that the optimum range was 0.28 to 11.0 (0.56 to 16.0$) \mu \mathrm{g}$ $\mathrm{mL}^{-1}$ iron (II) with $\mathrm{H}_{2}$ dapd (Hapm) reagents using direct and derivative modes. The concentration of iron was calculated by the regression equations (Table 1).

$\begin{aligned} & \text { Recommended Procedures for Direct and First } \\ & \text { for }\end{aligned}$
Derivative Spectrophotometry
Determination of Iron (II)
Procedure (I): A portion of ethanol solution was mixed with $1.0 \mathrm{~mL}$ of $0.1 \mathrm{M} \mathrm{HCl}$ (to adjust $\mathrm{pH}$ to 2.5), $1.0 \mathrm{~mL}$ of $0.1 \mathrm{M} \mathrm{NaNO}$, and $6.0 \mathrm{~mL}$ ultrapure water in a $10.0 \mathrm{~mL}$ flask. The solution was shaken for a few seconds. The final ethanol concentration was $10.0 \%$ in the medium. 
Table 1: Relationship Between Fe(II) Concentration $\left(\mathrm{mol} \mathrm{L}^{-1}\right.$ ) and Maximum Absorbance (in Direct Mode) and Vertical Amplitude (in Derivative Mode)

\begin{tabular}{|c|c|c|}
\hline Regression equation & $\mathrm{r}$ & Y residua \\
\hline \multicolumn{3}{|l|}{$\begin{array}{l}\text { Direct mode } \\
{\left[\mathrm{Fe}\left(\mathrm{H}_{2} \mathrm{dapd}\right)_{2}\right]^{2+*}}\end{array}$} \\
\hline $\mathrm{A}_{428}=\left(8481 \pm 1.82 \times 10^{-3}\right)\left[\mathrm{Fe}^{2+}\right]-\left(6.2 \times 10^{-3} \pm 4.7 \times 10^{-4}\right)$ & 0.9998 & $1.42 \times 10^{-3}$ \\
\hline $\begin{array}{l}\mathrm{A}_{502}=\left(7871 \pm 3.50 \times 10^{-3}\right)\left[\mathrm{Fe}^{2+}\right]-\left(4.0 \times 10^{-3} \pm 8.9 \times 10^{-4}\right) \\
{\left[\mathrm{Fe}(\mathrm{Hapm})_{3}\right]^{2+* *}}\end{array}$ & 0.9994 & $2.68 \times 10^{-3}$ \\
\hline $\begin{array}{l}\mathrm{A}_{524}=\left(6905 \pm 3.63 \times 10^{-3}\right)\left[\mathrm{Fe}^{2+}\right]-\left(4.2 \times 10^{-3} \pm 1.20 \times 10^{-4}\right) \\
\text { First derivative mode } \\
{\left[\mathrm{Fe}\left(\mathrm{H}_{2} \text { dapd }\right)_{2}\right]^{2+*}}\end{array}$ & 0.9997 & $2.49 \times 10^{-3}$ \\
\hline $\mathrm{D}_{412}=\left(169.6 \pm 5.90 \times 10^{-6}\right)\left[\mathrm{Fe}^{2+}\right]-\left(1.8 \times 10^{-3} \pm 1.5 \times 10^{-6}\right)$ & 0.9979 & $4.61 \times 10^{-6}$ \\
\hline $\mathrm{D}_{439}=\left(121.9 \pm 8.80 \times 10^{-7}\right)\left[\mathrm{Fe}^{2+}\right]-\left(5.3 \times 10^{-4} \pm 2.3 \times 10^{-7}\right)$ & 0.9994 & $6.89 \times 10^{-7}$ \\
\hline $\mathrm{D}_{481}=\left(63.90 \pm 4.10 \times 10^{-7}\right)\left[\mathrm{Fe}^{2+}\right]-\left(4.6 \times 10^{-4} \pm 1.0 \times 10^{-7}\right)$ & 0.9989 & $6.56 \times 10^{-7}$ \\
\hline $\begin{array}{l}\mathrm{D}_{523}=\left(217.6 \pm 8.40 \times 10^{-7}\right)\left[\mathrm{Fe}^{2+}\right]-\left(1.3 \times 10^{-4} \pm 2.2 \times 10^{-7}\right) \\
{\left[\mathrm{Fe}(\mathrm{Hapm})_{3}\right]^{2+* *}}\end{array}$ & 0.9998 & $3.19 \times 10^{-7}$ \\
\hline $\mathrm{D}_{480}=\left(76.00 \pm 5.80 \times 10^{-7}\right)\left[\mathrm{Fe}^{2+}\right]-\left(7.0 \times 10^{-4} \pm 1.9 \times 10^{-7}\right)$ & 0.9996 & $9.19 \times 10^{-7}$ \\
\hline $\mathrm{D}_{555}=\left(134.8 \pm 2.30 \times 10^{-6}\right)\left[\mathrm{Fe}^{2+}\right]-\left(9.0 \times 10^{-4} \pm 4.3 \times 10^{-7}\right)$ & 0.9997 & $3.99 \times 10^{-7}$ \\
\hline
\end{tabular}

$\mathrm{A}=$ Absorbance; $\mathrm{D}=\mathrm{dA} / \mathrm{d} \lambda=$ Vertical Amplitude from Zeroth Line; $\mathrm{r}=$ Correlation Coefficient; $* \mathrm{n}=10$ Measurements; $* * \mathrm{n}=10$ measurements

Table 2: Analytical Characteristics of Direct and First Derivative Modes

\begin{tabular}{|c|c|c|c|c|c|}
\hline \multirow[b]{2}{*}{$\begin{array}{l}\text { Sensitivity } \\
\mathrm{S}(\mathrm{b}) \mathrm{s}_{\mathrm{b}}\end{array}$} & \multicolumn{4}{|c|}{ Limit of detection (LOD) } & \multirow[b]{2}{*}{$\begin{array}{l}\text { Dyn. Range } \\
\mathrm{C}_{\mathrm{L}}(\mathrm{k}=3) \mathrm{C}_{\mathrm{q}}(\mathrm{k}=6) \mu \mathrm{g} \mathrm{mL}^{-1}\end{array}$} \\
\hline & $\mathrm{S}_{\mathrm{A}}$ & $\mathrm{y}_{\mathrm{B}}$ & $\mathrm{S}_{\mathrm{B}}$ & $\mathrm{y}_{\mathrm{L}}$ & \\
\hline $\begin{array}{l}\text { Direct Mode } \\
{\left[\mathrm{Fe}\left(\mathrm{H}_{2} \mathrm{dapd}\right)_{2}\right]^{2+} *}\end{array}$ & & & & & \\
\hline $\begin{array}{l}\lambda_{428} 0.1516 .71 \times 10^{-4} 4.44 \times 10^{-3} \\
{\left[\mathrm{Fe}(\mathrm{Hapm})_{3}\right]^{2+* *}}\end{array}$ & $2.13 \times 10^{-3}$ & $1.48 \times 10^{-4}$ & $2.20 \times 10^{-2}$ & $4.98 \times 10^{-3}$ & $0.010 .01-11$ \\
\hline $\begin{array}{l}\lambda_{524} 0.1231 .43 \times 10^{-3} 1.16 \times 10^{-3} \\
\text { Derivative Mode } \\
{\left[\mathrm{Fe}\left(\mathrm{H}_{2} \mathrm{dapd}\right)_{2}\right]^{2+*}}\end{array}$ & $3.29 \times 10^{-2}$ & $2.59 \times 10^{-3}$ & $3.53 \times 10^{-2}$ & $1.95 \times 10^{-2}$ & $0.040 .04-16$ \\
\hline $\begin{array}{l}\left(\mathrm{d}_{\mathrm{A}} / \mathrm{d} \lambda\right)_{523} 0.0043 .71 \times 10^{-7} 9.15 \times 10^{-5} \\
{\left[\mathrm{Fe}(\mathrm{Hapm})_{3}\right]^{2+* *}}\end{array}$ & $3.80 \times 10^{-4}$ & $4.47 \times 10^{-5}$ & $5.14 \times 10^{-4}$ & $3.40 \times 10^{-2}$ & $0.070 .07-11$ \\
\hline$\left(\mathrm{d}_{\mathrm{A}} / \mathrm{d} \lambda\right)_{555} 0.0025 .50 \times 10^{-7} 2.29 \times 10^{-4}$ & $4.60 \times 10^{-4}$ & $5.48 \times 10^{-5}$ & $6.24 \times 10^{-4}$ & $6.80 \times 10^{-2}$ & $0.140 .14-16$ \\
\hline
\end{tabular}

$\lambda_{\mathrm{m}}=$ Maximum Wavelength; $\mathrm{S}=$ Sensitivity=Slope of Calibration Curve; $\mathrm{s}_{\mathrm{b}}=$ Standard Deviation of Sensitivity; $\mathrm{S}_{\mathrm{A}}=$ Analytical Sensitivity; $\mathrm{y}_{\mathrm{B}}=$ Blank Signal; (Average of Five Measurements); $\mathrm{s}_{\mathrm{B}}=$ Standard Deviation of Blank; $\mathrm{y}_{\mathrm{L}}=$ Lowest Detectable Instrument Signal; $\mathrm{C}_{\mathrm{L}}=\mathrm{Limit}$ of Detection; $\mathrm{C}_{\mathrm{q}}=$ Limit of Quantification; dyn= Dynamic Range; * ( $\mathrm{n}=10$ measurements); ** $(\mathrm{n}=8$ measurements)

Procedure (II): A portion of ethanol solution containing $408.0 \mu \mathrm{g} \mathrm{Hapm,} 56.0 \mu \mathrm{g}$ of iron (II) was mixed with $4.0 \mathrm{~mL}$ ethanol, $1.0 \mathrm{~mL} 0.1 \mathrm{M} \mathrm{NaNO}$ and $2.0 \mathrm{~mL}$ ultrapure water into $10 \mathrm{~mL}$ beaker, stir the solution and the $\mathrm{pH}$ was adjusted to 7.5 with $\mathrm{NaOH}$. The final ethanol concentration was $60 \%$ in the medium.

Transfer both solutions to a $10.0 \mathrm{ml}$ flask and make up to the mark with ultrapure water. In procedures (I) and (II), the absorption (A) and amplitude signals $(\mathrm{dA} / \mathrm{d} \lambda)$ against a reagent blank were recorded. Then the concentration of ferrous ion as $\mathrm{Fe}$ (II) - and Fe (II) -Hapm complexes were measured at 428 (523) or 524 (555) NM with direct (first derivative) mode, (Table 1).

Determination the $\mathrm{Fe}$ (II) and $\mathrm{Fe}$ (III) in a Synthetic Solution: $\mathrm{X} \mathrm{mL}$ solutions containing 0.1675-1.117 $\mu \mathrm{g} \mathrm{mL}{ }^{-1} \mathrm{Fe}(\mathrm{III})$ and $1.0 \mathrm{~mL}$ of $1.0 \times 10^{-2} \mathrm{M}(0.5585$ $\left.\mu \mathrm{g} \mathrm{mL}^{-1}\right) \mathrm{Fe}(\mathrm{II})$ were placed in a flask and flow the nitrogen in the mixture. After duration for $15 \mathrm{sec}, \mathrm{y}$ $\mathrm{mL}$ of $1.0 \times 10^{-4} \mathrm{M} \mathrm{H}_{2}$ dapd, $1.0 \mathrm{~mL} 0.1 \mathrm{M} \mathrm{HCl}$ and $1.0 \mathrm{~mL}$ of $0.1 \mathrm{M} \mathrm{NaNO}$, were added. Dilute the mixture with water to the mark. The absorbance of total iron as $\mathrm{Fe}(\mathrm{II})-\mathrm{H}_{2}$ dapd complex was measured after standing $4 \mathrm{hr}$. The concentration of iron was calculated at $\lambda_{\mathrm{m}} 428 \mathrm{~nm}$ using regression equations (Table 1).

Determination of Total Iron in Herb, Spice, Bean and Rock Samples: The recommended procedure (I) was applied to determine iron in four herbs and spices (kakade, anise, cumin and black pepper), one Vicia faba bean (testa, cptyledons and testa+ cptyledons) and six rock samples. Four herbs and spice or six rock samples were purchased from a supermarket in Sohag area are collected from the red sea area, Upper Egypt. To prepare dry weight of herb, spice and bean, the samples washed with water to avoid any contamination on the surface $^{[15]}$. After drying, the samples were ground with titanium blade (food blender) to make the homogeneous and sieved to separate particle size fraction $(<150 \mu \mathrm{m})$. Whereas rock samples were ground with ceramic mortar and sieved to separate particle size fraction $(<150 \mu \mathrm{m})$. A certain amount of ground sample (herb, spice and bean) was heated at $500^{\circ} \mathrm{C}$ for $2 \mathrm{hr}$ in a muffle furnace. A $1.0 \mathrm{~g}$ of resultant or rock sample was mixed with $10 \mathrm{~mL}$ concentrated $\mathrm{HCl}$ and $\mathrm{HNO}_{3}$ (1:1). Evaporate tell appearance of white residue, then 
dissolve in $10 \mathrm{~mL}$ water and evaporated again. After cooling, $50.0 \mathrm{~mL}$ of water was added and the solution was filtered into a $100 \mathrm{~mL}$ flask, brought to volume. Aliquots of 1.0-3.0 or $5.0 \mathrm{ml}$ from an herb, spice and bean or rock solutions were used in spectrophotometric determination of iron by procedure (I). The absorbance of iron as $\left[\mathrm{Fe}\left(\mathrm{H}_{2} \mathrm{dapd}\right)_{2}\right]^{2+}$ complex was measured at 428 (523) nm using direct (first derivative) mode after standing $4 \mathrm{hr}$. The iron concentration was calculated using regression equations (Table 1).

\section{RESULTS AND DISCUSSION}

Effect of pH: The influence of $\mathrm{pH}$ on the formation of $\left.\mathrm{Fe}\left(\mathrm{H}_{2} \mathrm{dapd}\right)_{2}\right]^{2+}\left(\left[\mathrm{Fe}(\mathrm{Hapm})_{3}\right]^{2+}\right)$ complex in $10 \%(60 \%)$ $\mathrm{v} / \mathrm{v}$ water-ethanol mixture was studied in the $\mathrm{pH}$ range from 0.5 to 12.0 , Fig. $1(\mathrm{a}, \mathrm{b})$. Obviously, observance is constant and maximal at $\mathrm{pH}$ 2.0-3.0 (7.0-10.0) for $\mathrm{Fe}$ (II) $-\mathrm{H}_{2} \mathrm{dapd}$ (Fe (II) -Hapm) complex. So, pH 2.5 or 7.5 were selected for the iron (II) determination with $\mathrm{H}_{2}$ dapd or Hapm reagents.

Effect of Time on $\mathbf{H}_{2}$ dapd Reagent: Figure 2 (a) shows the influence of varying period times $(30.0 \mathrm{sec}$ to $12 \mathrm{hr}$ ) on the stability of $1.0 \times 10^{-3} \mathrm{M} \mathrm{H}_{2}$ dapd at $\mathrm{pH} 2.5$. Obviously, the absorbance at $\lambda_{\mathrm{m}} 297 \mathrm{~nm}$ attained constant value from $30 \mathrm{sec}$ to $4.0 \mathrm{hr}$ with relative error less than $1.8 \%$. On further increasing period times in 12 $\mathrm{hr}$, the absorbance decreases slowly with relative error range $2.5-11.2 \%$. After three days, the absorbance decreases rapidly with relative error $33 \%$. The same result is also found in $\lambda_{\mathrm{m}} 258 \mathrm{~nm}$, suggesting that $\mathrm{H}_{2}$ dapd reagent is stable within $4.0 \mathrm{hr}$. For this fact, it is advisable to prepare this reagent daily.

Oxidation-reduction Character of $\mathbf{H}_{\mathbf{2}}$ dapd: The presence of ascorbic acid does not affect the Fe (II) $\mathrm{H}_{2}$ dapd complex, whereas changes occur in the presence of $\mathrm{H}_{2} \mathrm{O}_{2}$. This observation revealed that $\mathrm{H}_{2}$ dapd reagent behaves as a reducing agent. To assess the ability and power of $\mathrm{H}_{2}$ dapd as a reducing agent, a study was carried out with four standard solutions: Two solutions contain 2.8 and $5.6 \mu \mathrm{g} \mathrm{mL} \mathrm{mL}^{-1} \mathrm{Fe}$ (II) with 18.3 $\mu \mathrm{g} \mathrm{mL}^{-1} \mathrm{H}_{2}$ dapd; Fig 2 (d, e), While other two solutions contain 2.5 and $5.6 \mu \mathrm{g} \mathrm{mL}^{-1} \mathrm{Fe}$ (III) with $38.6 \mu \mathrm{g} \mathrm{mL}^{-1}$ $\mathrm{H}_{2}$ dapd; Fig 2 (b,d), following the optimum condition of spectrophotometric procedure (I). The ratio between iron: reagent is about $1: 10$. The absorbance of Fe(II) or $\mathrm{Fe}(\mathrm{III})$ complexes at $\lambda_{\mathrm{m}} 428 \mathrm{~nm}$ after allowed periods range $30 \mathrm{sec}-12.0 \mathrm{hr}$ were measured. Figure $2(\mathrm{~b}, \mathrm{~d})$ shows that the observance of $\mathrm{Fe}$ (III) system increases gradually with increasing time from $30 \mathrm{sec}$ to $4.0 \mathrm{hr}$. With increasing time from 4 to $6.5 \mathrm{hr}$, the observance remains constant. At still increasing time, the absorbance decreases slowly. Figure 2(c,e) shows the rapid formation of the $\mathrm{Fe}$ (II)-complex indicating that $\mathrm{Fe}(\mathrm{II})$ complex is formed and it's stable for at least $8 \mathrm{hr}$ but with increasing time to $12 \mathrm{hr}$, absorbance decreases slowly.
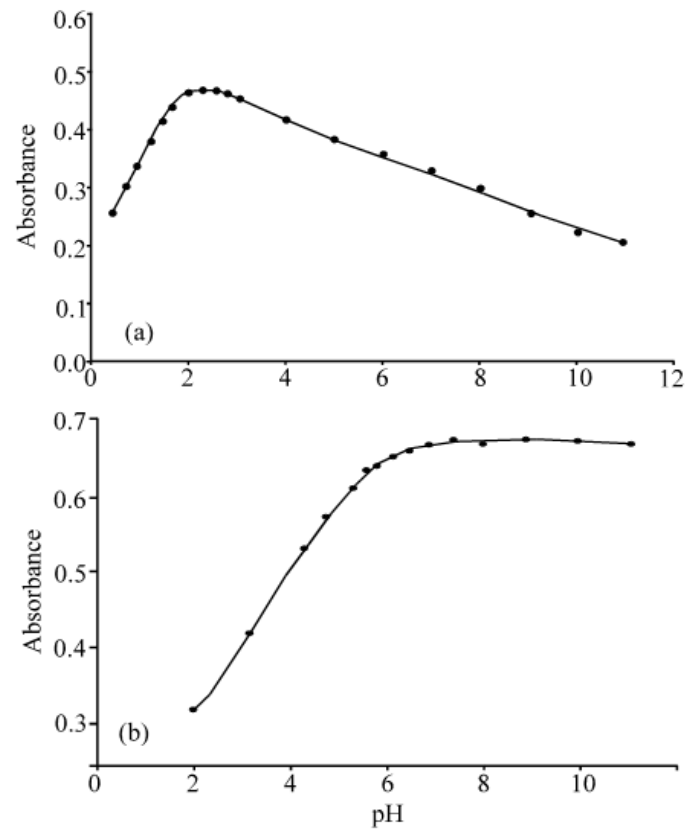

Fig. 1: Effect of $\mathrm{pH}$ on the $\mathrm{Fe}(\mathrm{II})-\mathrm{H}_{2}$ dapd and $\mathrm{Fe}(\mathrm{II})-$ Hapm systems: a)- $2.8 \mu \mathrm{g} \mathrm{mL} \mathrm{m}^{-1} \mathrm{Fe}(\mathrm{II})$ and 19.3 $\mu \mathrm{g} \mathrm{mL}^{-1} \mathrm{H}_{2}$ dapd; (b)- $5.6 \mu \mathrm{g} \mathrm{mL}^{-1} \mathrm{Fe}$ (II) and $40.8 \mu \mathrm{g} \mathrm{mL}^{-1} \mathrm{Hapm}$

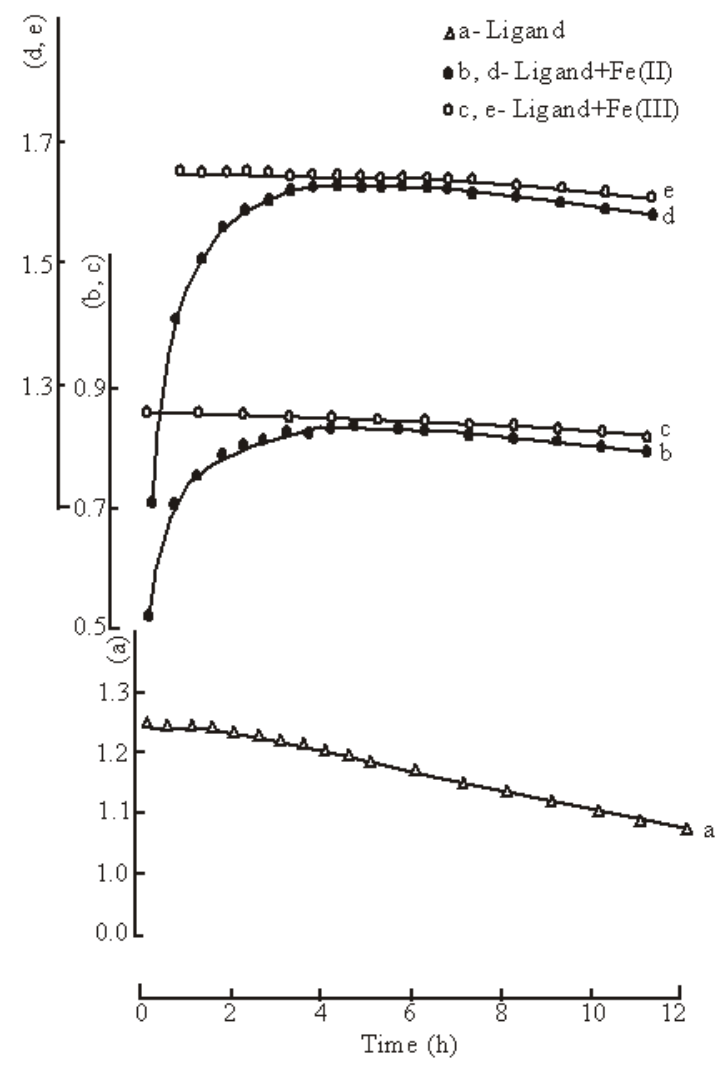

Fig. 2: Stability and radix character: (a) $19.3 \mathrm{mg} \mathrm{L}^{-1}$ $\mathrm{H}_{2}$ dapd; b or c) $\mathrm{a}+2.8$ or $5.6 \mu \mathrm{g} \mathrm{L}^{-1} \mathrm{Fe}$ (II) or $\mathrm{Fe}$ (III); d and e) $2 \mathrm{a}+2.8$ or $5.6 \mu \mathrm{g} \mathrm{L}^{-1} \mathrm{Fe}$ (II) or Fe (III) using a procedure (I). 


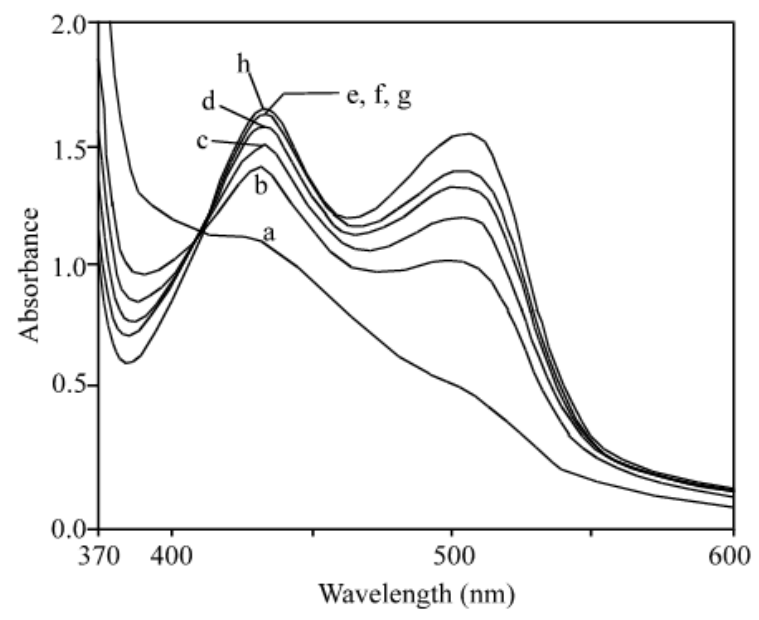

Fig. 3: Direct spectra obtained from a mixture of iron and $\mathrm{Fe}(\mathrm{II})$ in a solution containing $38.6 \mu \mathrm{g} \mathrm{L}^{-1}$ $\mathrm{H}_{2}$ dapd: a) $2.8 \mu \mathrm{g} \mathrm{mL}^{-1} \mathrm{Fe}(\mathrm{III})$ and $2.8 \mu \mathrm{g} \mathrm{mL}^{-}$ ${ }^{1} \mathrm{Fe}(\mathrm{II})$ at $30 \mathrm{sec}$; b) a at $0.5 \mathrm{hr}$; c) a at $1.0 \mathrm{hr}$; d) a at $2.0 \mathrm{hr} ;$ e) a at $3.5 \mathrm{hr} ; \mathrm{f}$ ) a at $4.0 \mathrm{hr} ; \mathrm{g}$ ) a at $6.0 \mathrm{hr}$; h) $5.6 \mu \mathrm{g} \mathrm{mL} \mathrm{m}^{-1} \mathrm{Fe}(\mathrm{II})$ at $30 \mathrm{sec}$.

Figure 2 (b, c, d, e), also shows that the maximum absorbance of $\mathrm{Fe}(\mathrm{II})$ or $\mathrm{Fe}(\mathrm{III})$ systems are nearly identical at time periods range 4.0-6.0 hr. This finding suggests that $\mathrm{Fe}(\mathrm{II})$ reacts with the $\mathrm{H}_{2}$ dapd reagent to form $\mathrm{Fe}(\mathrm{II})-\mathrm{H}_{2} \mathrm{dapd}$ complex at $30 \mathrm{sec}$ (instantaneously) whereas the reaction in $\mathrm{Fe}(\mathrm{III})$ system needs standing time within 4.0-6.5 hr forming $\mathrm{Fe}(\mathrm{II})-\mathrm{H}_{2}$ dapd complex. To confirm above results two solutions were prepared, one of them contains an iron mixture (2.5 ferric and 2.5 $\mu \mathrm{g} \mathrm{L}^{-1}$ ferrous) while the other contains only ferrous $\left(5.6 \mu \mathrm{g} \mathrm{L}^{-1}\right)$. Under the optimum condition of procedure $\mathrm{I}$, the absorbance of iron in iron mixture and $\mathrm{Fe}(\mathrm{II})$ systems at $\lambda_{\mathrm{m}} 428 \mathrm{~nm}$ were measured at seven different period time (30 sec-6 hr) and at $30 \mathrm{sec}$, respectively. The results are illustrated in Fig. 3. Obviously, the absorbance values in $\mathrm{Fe}$ (III) system increase gradually with increasing time of reaction. In addition, the absorbance value of Fe (III) system will be fixed at time ranges from 4 to $6 \mathrm{hr}$. Results also show that the recovery of ferric reduction to ferrous ion with $\mathrm{H}_{2}$ dapd are 73.6, 85.6, 91.6, 96.2, 99.1, 99.5 and $99.7 \%$ at 30 Sec, $0.5,1.0,2.0,3.5,4.0$ and $6.0 \mathrm{hr}$, respectively, assuming the standard value of absorbance for ferrous at $30 \mathrm{Sec}$. On the other hand, observance of iron in the ferrous system (curve h) at $30 \mathrm{Sec}$ is analogous with absorbance in iron mixture at 4.0 and $6.0 \mathrm{hr}$ (curves $\mathrm{f}$ and g). These observations reveal that $\mathrm{H}_{2}$ dapd reagent reduced ferric ion completely to ferrous within period at least $4 \mathrm{hr}$ without shift in $\lambda_{\mathrm{m}}(428 \mathrm{~nm})$. Also, ferrous ion in a binary mixture of ferric and ferrous ions could not be measured at $30 \mathrm{Sec}$, i.e. The reaction is instantaneous, resulting incomplete reduction process of ferric system.
Spectral Characteristics: The iron (II) reacts rapidly within a minute with $\mathrm{H}_{2}$ dapd and Hapm reagents forming. Stable red and orange complexes at $\mathrm{pH} 2.5$ and 7.5, respectively. Figure 4 shows the direct and first derivative spectra of $\mathrm{Fe}$ (II) $-\mathrm{H}_{2}$ dapd (curves a, á) and Fe-(II) -Hapm (curves b, b') complexes and their reagent blanks (curve c, ć, d, d). The absorption bands in direct mode of $\mathrm{Fe}(\mathrm{II})-\mathrm{H}_{2}$ dapd complex showed doubly absorption maximum at 428 and $502 \mathrm{~nm}$ while $\mathrm{Fe}(\mathrm{II}) \mathrm{Hapm}$ complex showed a singly absorption band at $524 \mathrm{~nm}$. The splitting band of $\left[\mathrm{Fe}\left(\mathrm{H}_{2} \mathrm{dapd}\right)_{2}\right]^{2+}$ complex indirect spectra was explained by a pronounced reduction in the ligand field caused by the greater stress requirements of the two legends molecules. Two absorption bands were assigned to the ${ }^{5} \mathrm{~A}_{1}$ and ${ }^{5} \mathrm{~B}_{1}$ states derived from the splitting of ${ }^{5} \mathrm{E}$ spectroscopic term in the tetragonal ligand ${ }^{[18]}$. Maximum amplitude in the first derivative mode for di(mono) complex appeared in 412, 439, 481 and 523 (480 and 555) NM.

Composition of the Complexes: The continuous variations and molar ratio methods were applied to ascertain the stoichiometric composition of Fe (II) $\mathrm{H}_{2}$ dapd or $\mathrm{Fe}$ (II) -Hapm complex at $\mathrm{pH} 2.5$ or 7.5. A $1: 2$ and $1: 3$ of the $\mathrm{Fe}$ (II) $-\mathrm{H}_{2}$ dapd and $\mathrm{Fe}$ (II) -Hapm complexes were indicated, respectively. The ratios are in agreement with that found by analysis of solid complexes with the CHN elemental analyzer and IR.

Selection of Wavelength: In order to select the best analytical signal for $\mathrm{Fe}(\mathrm{II})-\mathrm{H}_{2}$ dapd (Fe(II)-Hapm) complex, calibration graphs by direct or derivative modes were plotted at $\lambda_{\mathrm{m}} 428$ and $502(524) \mathrm{nm}$ or 412, 439, 481 and 523 (480 and 555), respectively. Linear equations $(y=b x+a)$ of $A$ or $D$ signal against $F e$ (II) concentration for both complexes were listed in Table 1. Molar absorptivity in direct and derivative modes of $\mathrm{Fe}(\mathrm{II})-\mathrm{H}_{2}$ dapd (Fe(II)-Hapm) complexes were $8.481 \times 10^{3}\left(6.905 \times 10^{3}\right) \mathrm{L} \mathrm{mol}^{-1} \mathrm{~cm}^{-1}$ at 428 and $524 \mathrm{~nm}$ and 217.6 (134) $\mathrm{L} \mathrm{mol}^{-1} \mathrm{~cm}^{-1}$ at 523 (555) nm, respectively, suggesting that $\mathrm{H}_{2}$ dapd ligand is the best one for determining iron(II). Miller ${ }^{[19]}$ has indicated that if the $\mathrm{r}$ closes 1 or -1 , the gentle calibration graph is obtained. Table 1 shows a slight deviation from ideal linear. This deviation is attributed to random experimental errors, which make difficult to select the best wavelength or pulse amplitude. Accordingly, $\hat{y}$ and $y-\hat{y}$ residuals are introduced. Y-ŷy represents the difference between the experimental y values and fitted $\hat{y}$ values. By comparing $\hat{y}$-residual in direct and derivative modes for both irons-complexes, results show that low value in $\hat{y}$-residual appeared at $\lambda_{\mathrm{m}} 428$ and $\mathrm{D}$ at $523 \mathrm{~nm}$ for $\left[\mathrm{Fe}\left(\mathrm{H}_{2} \mathrm{dapd}\right)_{2}\right]^{2+}$ complex. 

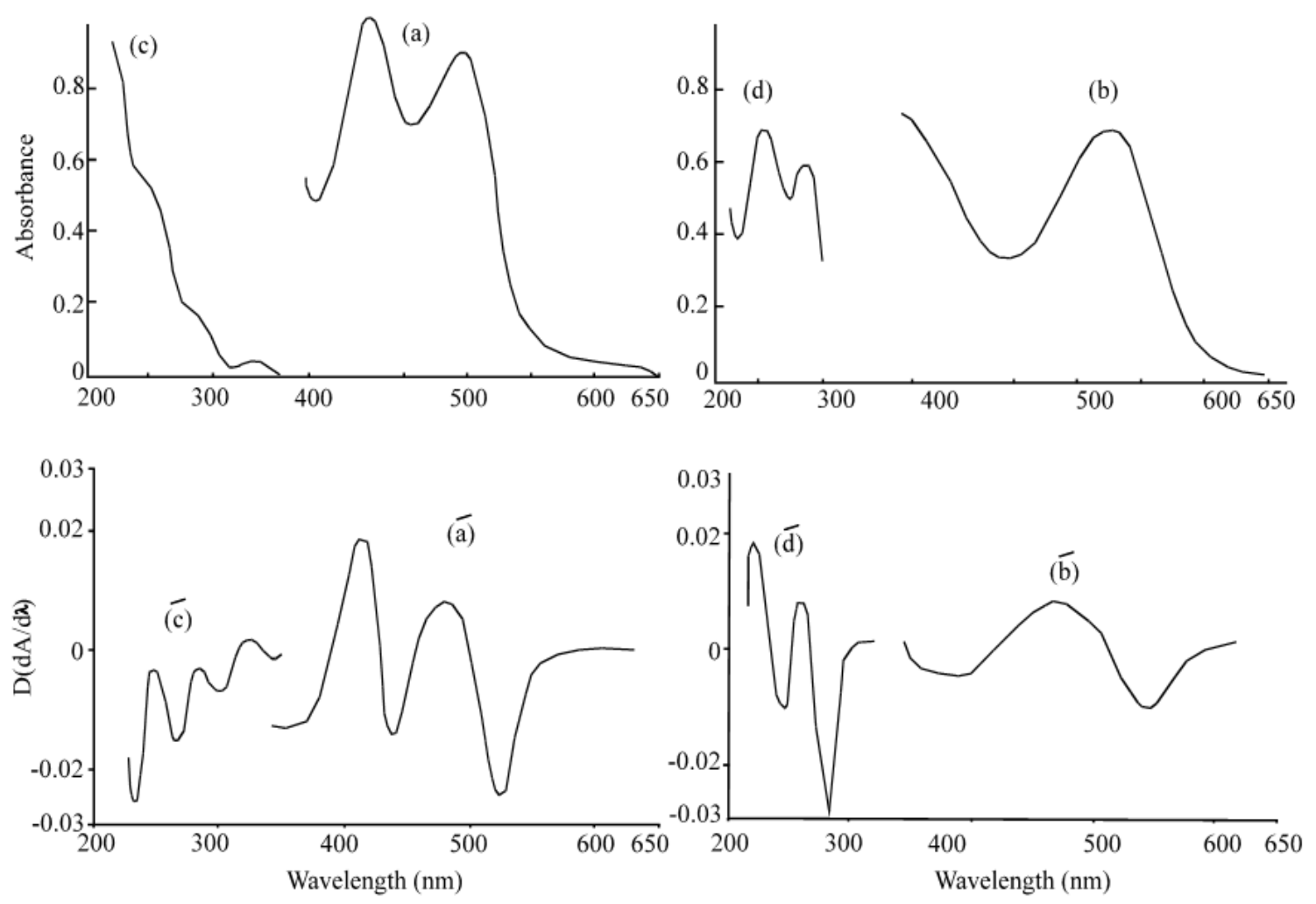

Fig. 4: Direct (a, b, c, d) and first derivative (a`, b', c', d') spectra of $\left[\mathrm{Fe}\left(\mathrm{H}_{2} \mathrm{dapd}\right)_{2}\right]^{2+},\left[\mathrm{Fe}(\mathrm{Hapm})_{3}\right]^{2+}, \mathrm{H}_{2} \mathrm{dapd}$ and Hapm. Conditions: (a,a`) $6.72 \mu \mathrm{g} \mathrm{mL} \mathrm{m}^{-1} \mathrm{Fe}(\mathrm{II})+46.32 \mu \mathrm{g} \mathrm{mL}^{-1} \mathrm{H}_{2} \mathrm{dapd}$; (b,b) $5.6 \mu \mathrm{g} \mathrm{mL}^{-1} \mathrm{Fe}$ (II)+40.8 $\mu \mathrm{g} \mathrm{mL} L^{-1} \mathrm{Hapm}$, (c,c') $46.32 \mu \mathrm{g} \mathrm{mL} \mathrm{L}^{-1} \mathrm{H}_{2} \mathrm{dapd}$; (d,d) $40.8 \mu \mathrm{g} \mathrm{mL} \mathrm{m}^{-1} \mathrm{Hapm}$

This is confirmed graphically, on plotting individual yŷ-residuals $v s$. y signals (Fig. 5). Clearly, Fig. 5 (a, á) shows that the residuals should thus take if the unweighted regression line is a good model for the experimental spectra. There is a clear sequence of the positive residual, followed by sequence negative ones followed by a second positive sequence. The three numbers of runs give a significant data. While Fig. 5 (b, b) shows that, the regression line is inappropriate. Because the sign (+) or (-) of the residual is in random. Therefore, results indicate that $\mathrm{H}_{2}$ dapd reagent is considered the best reagent for iron(II) determination at 428 and $523 \mathrm{~nm}$ with direct and first derivative, respectively, while iron(II) measurement with Hapm reagent at $524(555) \mathrm{nm}$ with direct (first derivative) is inappropriate.

Sensitivity, Detection Limits, Dynamic Range, Accuracy and Precision: Analytical sensitivity $\left(\mathrm{S}_{\mathrm{A}}\right)^{[20]}$, detection limit $\left(\mathrm{y}_{\mathrm{L}}\right)$ and dynamic range ${ }^{[20]}$ of Iron (II) determination as $\left[\mathrm{Fe}\left(\mathrm{H}_{2} \text { dapd }\right)_{2}\right]^{2+}$ and $\left[\mathrm{Fe}(\mathrm{Hapm})_{3}\right]^{2+}$ are summarized in Table 2. It is found that, direct and first order methods with $\mathrm{H}_{2}$ dapd reagent were sensitive with low detection limits than that obtained with Hapm suggesting, iron(II) can be successfully measured with procedure I.
The accuracy and precision of I and II procedures were checked by analyzing two sets of 2.8 and $5.6 \mu \mathrm{g} \mathrm{mL}^{-1}$ iron (II). Under the optimum conditions of a procedure I and II, ferrous ion as $\left[\mathrm{Fe}\left(\mathrm{H}_{2} \mathrm{dapd}\right)_{2}\right]^{2+}([\mathrm{Fe}$ (Hapm) $\left.{ }_{3}\right]^{2+}$ ) was measured at $\lambda_{\mathrm{m}} 428$ and $523 \mathrm{NM}$ is using direct and $\mathrm{D}$ at 524 and 555 using first derivative, respectively. The mean value and standard deviation for a procedure I or II were $2.85(0.018$ or $5.55(0.021$ using direct and $2.81\left(0.021\right.$ or $5.72\left(0.018 \mu \mathrm{g} \mathrm{mL}^{-1}\right.$ iron (II) using first derivative, while relative errors were 0.71 and $0.35 \%$ for direct and 5.0 and $2.8 \%$ for the first derivative, respectively. Thus, $\left.\mathrm{Fe}\left(\mathrm{H}_{2} \mathrm{dapd}\right){ }_{2}\right]^{2+}$ complex has the advantages of reasonable selectivity, good precision and low detection limit than Fe (Hapm) $\left.{ }_{3}\right]^{2+}$ complex.

Effect of Foreign Ions: The effect of 24 foreign ions on the determination of 2.8 or $5.6 \mu \mathrm{g} \mathrm{mL}^{-1}$ iron (II) with $\mathrm{H}_{2}$ dapd or Hapm reagent were examined individually by measuring the absorbance and vertical distance under the recommended procedures I and II. Metal ions were added as $\mathrm{Na}^{+}$or $\mathrm{K}^{+}$while the anions was added as $\mathrm{NO}_{3}{ }^{-}$ions. The tolerance limit was taken as the amount that caused $2.5 \%$ error. The results are given in Table 3. 

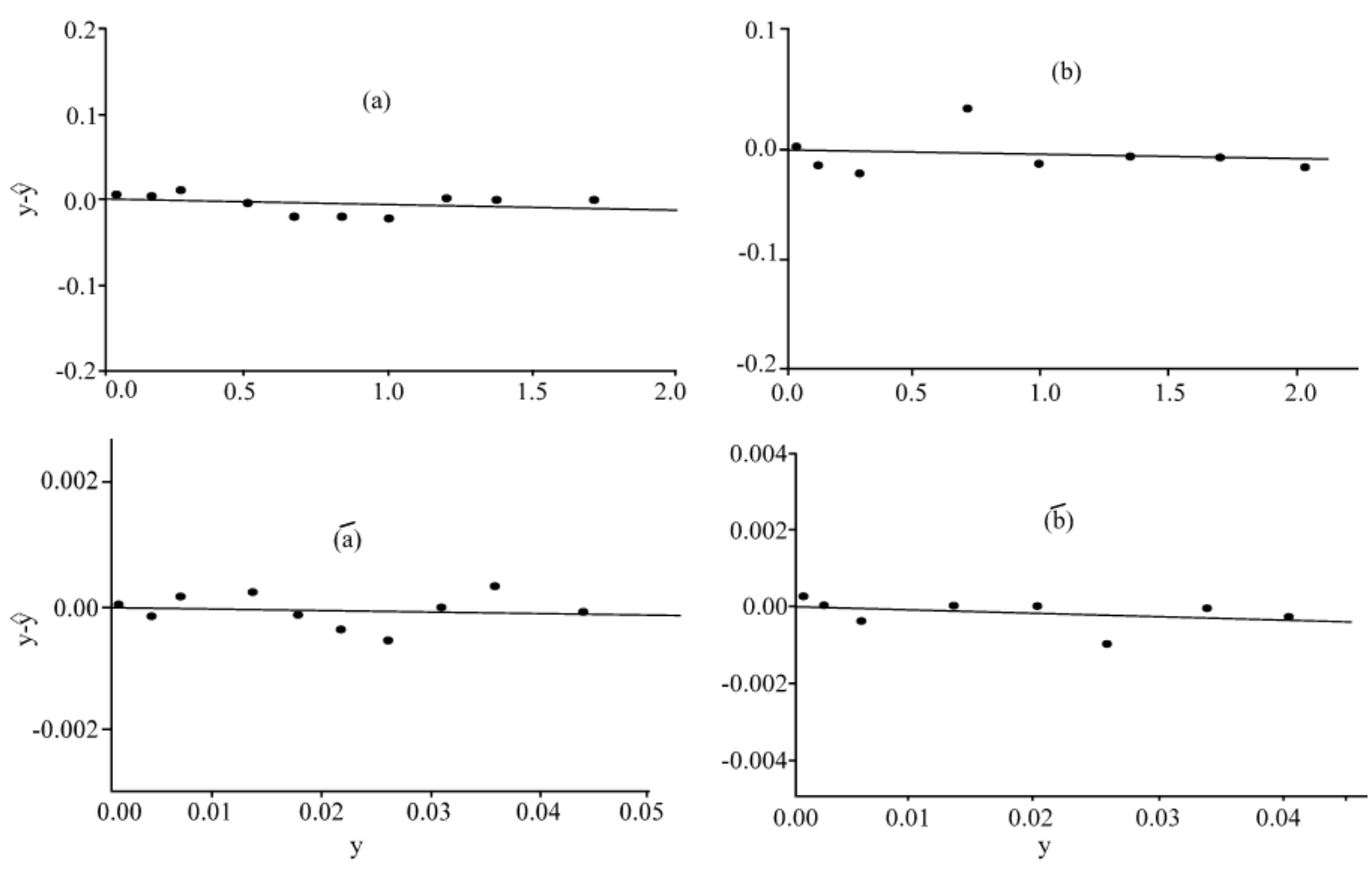

Fig. 5: Relation between individual $\hat{y}$-residual of calibration and y signal for direct $(a, b)$ and first derivative (a`,$\left.b^{\prime}\right)$ : (a) $\left[\mathrm{Fe}\left(\mathrm{H}_{2} \mathrm{dapd}\right)_{2}\right]^{2+}$ at $428 \mathrm{~nm},\left(\mathrm{a}^{-}\right)\left[\mathrm{Fe}\left(\mathrm{H}_{2} \mathrm{dapd}\right)_{2}\right]^{2+}$ at $523 \mathrm{~nm}$, (b) $\left[\mathrm{Fe}(\mathrm{Hapm})_{3}\right]^{2+}$ at $524 \mathrm{~nm}$ and (b') $\left[\mathrm{Fe}(\mathrm{Hapm})_{3}\right]^{2+}$ at $555 \mathrm{~nm}$

Tolerance limit of iron (II) as $\left.\mathrm{Fe}\left(\mathrm{H}_{2} \text { dapd }\right)_{2}\right]^{2+}$ in presence of $\mathrm{Cu}^{2+}, \mathrm{Cr}^{3+}, \mathrm{Ni}^{2+}$ and $\mathrm{Co}^{2+}$, with direct and derivative modes is higher than that obtained with $[\mathrm{Fe}$ $\left.(\text { Hapm })_{3}\right]^{2+}$ complex. Derivative spectra improved the tolerance limit of iron (II) fold twice than the direct spectra.

Figure 6 shows the influence of $0.152(0.044) \mathrm{mg}$ $\mathrm{mL}^{-1} \mathrm{Cu}^{2+}, 0.155$ (0.052) $\mathrm{mg} \mathrm{mL}^{-1} \mathrm{Cr}^{3+}, 0.017$ (0.007) $\mathrm{mg} \mathrm{mL}{ }^{-1} \mathrm{Ni}^{2+}$ and 0.017 (0.009) $\mathrm{mg} \mathrm{mL}^{-1} \mathrm{Co}^{2+}$, an iron (II) as $\left[\mathrm{Fe}\left(\mathrm{H}_{2} \mathrm{dapd}\right)_{2}\right]^{2+}\left(\left[\mathrm{Fe}(\mathrm{Hapm})_{3}\right]^{2+}\right)$. Obviously, the amplitude signal in the first derivative (D) of iron (II) as $\left[\mathrm{Fe}\left(\mathrm{H}_{2} \text { dapd }\right)_{2}\right]^{2+}$ complex was not affected with no significant difference in the presence of $\mathrm{Cu}^{2+}, \mathrm{Cr}^{3+}$, $\mathrm{Ni}^{2+}$ and $\mathrm{Co}^{2+}$ ions (Fig. 6á), while indirect mode, the observance of iron (II) -complex affected seriously with them ions (Fig. 6a), suggesting that $\mathrm{Cu}^{2+}, \mathrm{Cr}^{3+}, \mathrm{Ni}^{2+}$ and $\mathrm{Co}^{2+}$, interfering ions are completely masked with derivative mode. In contrast, direct and derivative spectra of iron (II) as $\left[\mathrm{Fe}(\mathrm{Hapm})_{3}\right]^{2+}$ could not prevent the deviation in $\mathrm{A}$ and $\mathrm{D}$, respectively, as shown in (Fig. $6 \mathrm{~b}, \mathrm{~b}$ ). Thus, the first derivative mode is used successfully for the determination of iron (II) with the H2dapd reagent in presence $\mathrm{Cu}^{2+}, \mathrm{Cr}^{3+} \mathrm{Ni}^{2+}$ and $\mathrm{Co}^{2+}$, ions. Although $\mathrm{H}_{2}$ dapd reagent improved tolerance limits two folds with first derivative spectra, values of $\mathrm{Ni}^{2+}$ and $\mathrm{Co}^{2+}$ ions are still low (Table 3). This is possibly attributed to the formation of $\mathrm{Ni}^{2+}$ dimmer complexes $\left[\mathrm{Ni}\left(\mathrm{H}_{2} \mathrm{dapd}\right)_{2}\right]^{2+}$ and $\left[\mathrm{Ni}(\mathrm{dapd})_{2}\right]^{2+}$ and quite oxidation of $\mathrm{Co}^{2+}$ to $\mathrm{Co}^{3+}$ in presence of $\mathrm{H}_{2}$ dapd ligand $^{[21,12]}$.
To drive a linear regression equation for iron (II) as [Fe $\left.\left(\mathrm{H}_{2} \text { dapd }\right)_{2}\right]^{2+}$ complex in the presence of four serious interfering ions, a series of a synthetic solution containing a varied concentration range 1.2-7.84 $\mu \mathrm{g}$ $\mathrm{mL}^{-1} \mathrm{Fe}$ (II) and fixed concentration of $\mathrm{H}_{2}$ dapd $(70 \mu \mathrm{g}$ $\mathrm{mL}^{-1}$ ) reagent in the presence of $0.152 \mathrm{mg} \mathrm{mL}^{-1} \mathrm{Cu}^{2+}$, $0.155 \mathrm{mg} \mathrm{mL}^{-1} \mathrm{Cr}^{3+}$ and $0.017 \mathrm{mg} \mathrm{mL}^{-1} \mathrm{Ni}^{2+}$ and $\mathrm{Co}^{2+}$, were prepared. The optimum condition of the procedure I was applying. The vertical distance of amplitude signal to zero line (D) against blank was recorded at derivative amplitude (D) $523 \mathrm{~nm}$. A linear calibration graphs passing through the origin is obtained by plotting DA/d (at $523 \mathrm{NM}$ versus iron (II) concentration. The regression equation in derivative mode ( $95 \%$ confidence interval, $\mathrm{n}=8$ ) is:

$\mathrm{D}_{523}=\left(3.92 \times 10^{-3} \pm 1.18 \times 10^{-6}\right)\left[\mathrm{Fe}^{2+}\right]-\left(3.60 \times 10^{-4} \pm 1.66 \times 10^{-6}\right)$

Determination of Iron in a Mixture Containing Fe (II) and Fe (III) Synthetic Solution: Table 4 shows the concentration of iron mixture in synthetic solution containing $0.5585 \mathrm{mg} \mathrm{mL}^{-1} \mathrm{Fe}$ (II), varied concentration of $\mathrm{Fe}$ (III) ranges $0.1675-1.1170 \mu \mathrm{g} \mathrm{mL}^{-1}$ in the presence of $1.0 \mathrm{ml} 0.1 \mathrm{M} \mathrm{HCl}$ and $1.0 \mathrm{ml} 0.1 \mathrm{M}$ $\mathrm{NaNO}_{3}$.

The absorbance of iron mixture was recorded under the optimum condition of procedure I $\left(0.1 \mathrm{M} \mathrm{NaNO}_{3}, \mathrm{pH}\right.$ $=2.5$ and $10 \%$ ethanol) after standing $4 \mathrm{hr}$ at $\lambda_{\mathrm{m}} 428 \mathrm{~nm}$. 

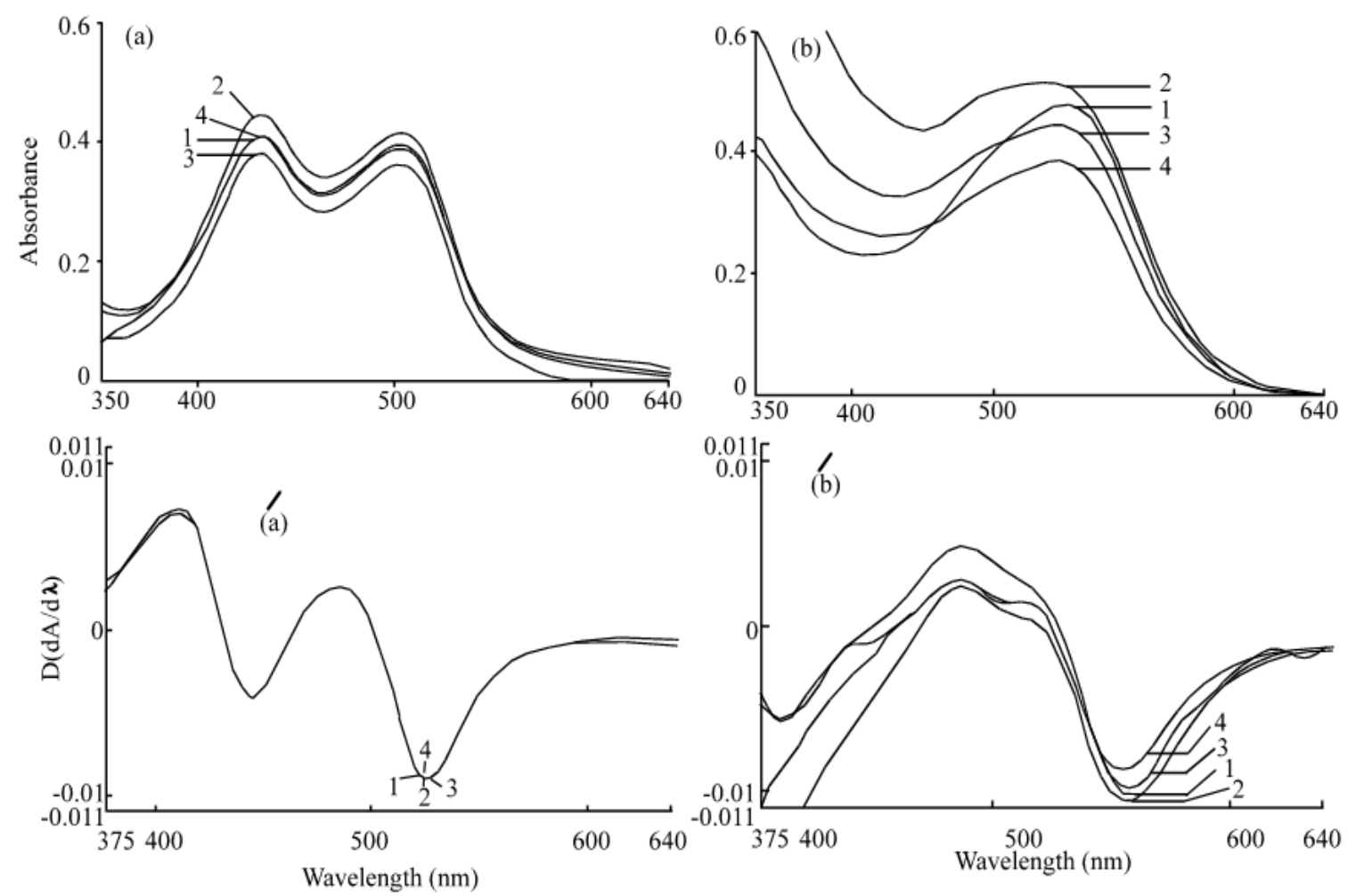

Fig. 6: Direct (a, b) and first derivative (á, b́) spectra of solution containing 19.3 (40.8) $\mu \mathrm{g} \mathrm{mL}^{-1} \mathrm{H}_{2} \mathrm{dapd}$ (Hapm) reagent, 15 (60) \% ethanol, $0.1 \mathrm{M} \mathrm{NaNO}_{3}$ at $\mathrm{pH} 2.5$ (7.5):

1: (a, á, b, b́): $2.8 \times 10^{-3}$ and $5.6 \times 10^{-3} \mathrm{mg} \mathrm{mL}^{-1} \mathrm{Fe}$ (II) as $\left[\mathrm{Fe}\left(\mathrm{H}_{2} \mathrm{dapd}\right)_{2}\right]^{2+}$ and $\left[\mathrm{Fe}(\mathrm{Hapm})_{3}\right]^{2+}$,

2: (a, á, b, b): 1 (a) +0.017 and $0.007 \mathrm{mg} \mathrm{mL}^{-1} \mathrm{Ni}^{2+}$ with $\left[\mathrm{Fe}\left(\mathrm{H}_{2} \mathrm{dapd}\right)_{2}\right]^{2+}$ and $\left[\mathrm{Fe}(\mathrm{Hapm})_{3}\right]^{2+}$,

3: (a, a , b, b): 1 (a) +0.017 and $0.009 \mathrm{mg} \mathrm{mL}^{-1} \mathrm{Co}^{2+}$ for $\left[\mathrm{Fe}\left(\mathrm{H}_{2} \mathrm{dapd}\right)_{2}\right]^{2+}$ and $\left[\mathrm{Fe}(\mathrm{Hapm})_{3}\right]^{2+}$,

4: (a, a , b, b): 1 (a) +0.152 and $0.044 \mathrm{mg} \mathrm{mL}^{-1} \mathrm{Cu}^{2+}$ for $\left[\mathrm{Fe}\left(\mathrm{H}_{2} \mathrm{dapd}\right)_{2}\right]^{2+}$ and $\left[\mathrm{Fe}(\mathrm{Hapm})_{3}\right]^{2+}$,

5: (a, a', b, b'): 1 (b) +0.155 and $0.052 \mathrm{mg} \mathrm{mL}^{-1} \mathrm{Cr}^{3+}$ for $\left[\mathrm{Fe}(\mathrm{Hapm})_{3}\right]^{2+}$ and $\left[\mathrm{Fe}(\mathrm{Hapm})_{3}\right]^{2+}$

Table 3: Effect of Diverse Ions Amounts of Fe (II) Taken 2.8 (5.6) $\mu \mathrm{g} \mathrm{mL}^{-1}$ with $\mathrm{H}_{2}$ dapd (Hapm) Reagent

\begin{tabular}{|c|c|c|c|c|}
\hline \multirow{2}{*}{$\begin{array}{l}{\left[\mathrm{Fe}\left(\mathrm{H}_{2} \mathrm{dapd}\right)_{2}\right]^{2+}} \\
\text { Diverse ions }\end{array}$} & \multirow[t]{2}{*}{ Tolerance limits } & \multicolumn{2}{|l|}{$\left[\mathrm{Fe}(\mathrm{Hapm})_{3}\right]^{2+}$} & \multirow[t]{2}{*}{ Tolerance limit } \\
\hline & & Diverse ions & $(w / w)$ & \\
\hline \multicolumn{5}{|l|}{ Direct mode } \\
\hline $\mathrm{K}^{+}, \mathrm{Na}^{+}, \mathrm{Ca}^{2+}$ & $<1000$ & $\mathrm{~K}^{+}, \mathrm{Na}^{+}, \mathrm{Ca}^{2+}$ & & $<1000$ \\
\hline $\mathrm{NO}_{3}{ }^{-}, \mathrm{Cl}^{-}, \mathrm{C}_{2} \mathrm{O}_{4}{ }^{2-}$ & & $\mathrm{La}^{3+}, \mathrm{Cd}^{2+}$ & & \\
\hline \multirow[t]{2}{*}{$\mathrm{Ce}^{4+}, \mathrm{La}^{3+}, \mathrm{Cd}^{2+}, \mathrm{Zn}^{2+}$} & & $\mathrm{SO}_{4}^{2-}$ & & $<900$ \\
\hline & & $\mathrm{Zn}^{2+}$ & & $<590$ \\
\hline $\mathrm{Mg}^{2+}, \mathrm{Ba}^{2+}, \mathrm{Th}^{4+}$ & $<500$ & $\mathrm{Mg}^{2+}, \mathrm{Th}^{4+}, \mathrm{Ce}^{4+}$, & & $<207$ \\
\hline $\mathrm{SCN}^{-}, \mathrm{CN}^{-}$ & & $\mathrm{NO}_{3}^{-}, \mathrm{Cl}^{-}, \mathrm{C}_{2} \mathrm{O}_{4}{ }^{2}$ & & \\
\hline $\mathrm{U}^{6+}$ & $<253$ & $\mathrm{U}^{6+}$ & & $<84$ \\
\hline \multirow[t]{2}{*}{$\mathrm{Pb}^{2+}, \mathrm{Mn}^{2+}$} & $<118$ & $\mathrm{~Pb}^{2+}, \mathrm{Mn}^{2+}$ & & $<29$ \\
\hline & & $\mathrm{SCN}^{-}, \mathrm{CN}^{-}$ & & \\
\hline $\mathrm{Cu}^{2+} *$ & $<36$ & $\mathrm{Cu}^{2+} *$ & & $<7.9$ \\
\hline $\mathrm{Cr}^{3+*}$ & $<28$ & $\mathrm{Cr}^{3+*}$ & & $<9.3$ \\
\hline $\mathrm{Ni}^{2+*}$ & $<2.5$ & $\mathrm{Ni}^{2+} *$ & & $<1.25$ \\
\hline $\mathrm{Co}^{2+*}$ & $<3.0$ & $\mathrm{Co}^{2+} *$ & & $<1.60$ \\
\hline \multicolumn{5}{|c|}{ First Derivative Mode } \\
\hline $\mathrm{Cu}^{2+*}$ & $<54$ & $\mathrm{Cu}^{2+} *$ & & $<7.9$ \\
\hline $\mathrm{Cr}^{3+*} *$ & $<55$ & $\mathrm{Cr}^{3+*}$ & & $<9.3$ \\
\hline $\mathrm{Ni}^{2+*}$ & $<6.0$ & $\mathrm{Ni}^{2+} *$ & & $<1.25$ \\
\hline $\mathrm{Co}^{2+*}$ & $<6.0$ & $\mathrm{Co}^{2+} *$ & & $<1.60$ \\
\hline
\end{tabular}


Table 4: Results the Determination of a Mixture Containing Fixed or Variable Concentration of Fe (II) or Fe (III) with $19.3 \mu \mathrm{g} \mathrm{mL} \mathrm{m}^{-1} \mathrm{H}_{2} \mathrm{dapd}$ Reagent ( $\mathrm{I}=0.1 \mathrm{M} \mathrm{NaNo}_{3}, 10 \%$ Ethanol at $\left.\mathrm{pH} 2.5\right)$

\begin{tabular}{llllll}
\hline $\begin{array}{l}\text { True value } \\
\text { Fe(II) } \\
\mu \mathrm{g} \mathrm{mL}^{-1}\end{array}$ & $\begin{array}{l}\text { Found value } \\
\text { Fe(III) } \\
\mu \mathrm{g} \mathrm{mL}^{-1+}\end{array}$ & $\begin{array}{l}\text { Total iron } \\
\mu \mathrm{g} \mathrm{m}^{-1}\end{array}$ & Absorbance & $\begin{array}{l}\text { Total iron } \\
\mu \mathrm{gL}^{-1}\end{array}$ & $\begin{array}{l}\text { Recovery } \\
\%\end{array}$ \\
\hline 0.5585 & 0.1675 & 0.7260 & $1.0956 \pm 2.1 \times 10^{-3}$ & 0.7253 & 99.9 \\
& 0.3351 & 0.8936 & $1.3465 \pm 1.7 \times 10^{-2}$ & 0.8905 & 99.6 \\
& 0.5585 & 1.1170 & $1.6789 \pm 1.9 \times 10^{-3}$ & 1.1095 & 99.3 \\
& 0.8377 & 1.3962 & $2.0879 \pm 2.3 \times 10^{-3}$ & 1.3787 & 98.7 \\
\hline
\end{tabular}

Table 5: Direct and First Derivative Measurements of Iron (II) as $\left[\mathrm{Fe}\left(\mathrm{H}_{2} \mathrm{dapd}\right)_{2}\right]^{2+}$ Complex in Beans, Herbs Species and Rocks

\begin{tabular}{|c|c|c|c|c|c|}
\hline $\begin{array}{l}\text { No. of } \\
\text { samples }\end{array}$ & $\begin{array}{l}\text { Direct Mode } \\
\mathrm{mg} \mathrm{g}^{-1}( \pm \mathrm{sd})\end{array}$ & $\begin{array}{l}\text { Derivative Mode } \\
\mathrm{mg} \mathrm{g}^{-1}( \pm \mathrm{sd})\end{array}$ & $\begin{array}{l}\text { AAS } \\
\mathrm{mg} \mathrm{g}^{-1}( \pm \mathrm{sd}) \\
\end{array}$ & $\begin{array}{l}\text { Relative Errors } \\
\text { direct-AAS }\end{array}$ & D-AAS \\
\hline \multicolumn{6}{|c|}{ Herbs, Spices and beans } \\
\hline 1 & $10.19( \pm 0.04)$ & $11.09( \pm 0.05)$ & $10.58( \pm 0.07)$ & 3.69 & 4.82 \\
\hline 2 & $3.75( \pm 0.05)$ & $4.14( \pm 0.06)$ & $3.95( \pm 0.05)$ & 5.06 & 4.81 \\
\hline 3 & $7.45( \pm 0.02)$ & $8.07( \pm 0.03)$ & $7.74( \pm 0.15)$ & 3.75 & 4.26 \\
\hline 4 & $7.95( \pm 0.03)$ & $8.69( \pm 0.06)$ & $8.33( \pm 0.02)$ & 4.56 & 4.32 \\
\hline 5 & $5.12( \pm 0.07)$ & $5.49( \pm 0.07)$ & $5.32( \pm 0.11)$ & 3.76 & 3.19 \\
\hline 6 & $4.09( \pm 0.05)$ & $4.45( \pm 0.06)$ & $4.29( \pm 0.14)$ & 4.66 & 3.73 \\
\hline 7 & $8.88( \pm 0.04)$ & $9.14( \pm 0.05)$ & $8.98( \pm 0.04)$ & 1.11 & 1.78 \\
\hline \multicolumn{6}{|l|}{ Rocks } \\
\hline 8 & $72.87( \pm 1.72)$ & $76.04( \pm 1.09)$ & $75.0( \pm 3.22)$ & 2.84 & 1.39 \\
\hline 9 & $85.85( \pm 1.27)$ & $89.15( \pm 1.26)$ & $88.15( \pm 2.44)$ & 2.61 & 1.13 \\
\hline 10 & $75.77( \pm 1.53)$ & $77.50( \pm 1.04)$ & $75.96( \pm 3.09)$ & 0.25 & 2.03 \\
\hline 11 & $34.97( \pm 1.06)$ & $37.50( \pm 1.27)$ & $36.30( \pm 1.76)$ & 3.66 & 3.30 \\
\hline 12 & $7.56( \pm 0.04)$ & $8.12( \pm 0.05)$ & $7.88( \pm 0.19)$ & 4.06 & 3.04 \\
\hline 13 & $72.87( \pm 1.72)$ & $76.04( \pm 1.09)$ & $100.8( \pm 2.08)$ & 3.12 & 2.18 \\
\hline
\end{tabular}

1-kakade; 2- anise; 3- cumin; 4- black pepper; 5- testa of Vicia faba; 6- cotyledons of Vicia faba; 7- testa and cotyledons; (8-10)- amphibolites; $(11,12)$ - migmatite lecsome; 13- serpentine; D Derivative Spectra; AAS = Atomic Absorption Spectrophtometric

There is a good agreement between true and found concentration of iron. The recovery of measurements was found to be higher than $99.3 \%$. Thus, $\mathrm{H}_{2}$ dapd reagent can be recommended for the determination of total iron in a mixture containing ferrous and ferric mixture as $\left[\mathrm{Fe}\left(\mathrm{H}_{2} \mathrm{dapd}\right)_{2}\right]^{+2}$ complex after an allowed period of $4 \mathrm{hr}$ for complete reduction $\mathrm{Fe}$ (III) to $\mathrm{Fe}(\mathrm{II})$.

\section{Determination of Total Iron in Outdoor Samples} Using $\mathbf{H}_{\mathbf{2}}$ dapd Reagent: The proposed procedure I was applied to determine iron in herb, spice, bean (rock) after wet ashing (wet digestion) of the samples. The results are listed in Table 5. The method based on the reduction of $\mathrm{Fe}(\mathrm{III})$-complex to $\mathrm{F}$ (II)-complex with $\mathrm{H}_{2}$ dapd reagent after standing for $4 \mathrm{hr}$. The A or D signals were measured at 428 or $523 \mathrm{~nm}$, respectively against the blank solution. The results obtained were compared with that measured by AAS. There are agreements between the results obtained by direct and derivative modes and AAS. No significant differences are observed $(\mathrm{F}=1.048$ in direct mode-AAS and $\mathrm{F}=1$. 032 in derivative mode-AAS). The relative error was found to be less than $5 \%$. Thus, $\mathrm{H}_{2}$ dapd reagent can be used successfully to determine total iron as $[\mathrm{Fe}$ $\left.\left(\mathrm{H}_{2} \text { dapd }\right)_{2}\right]^{2+}$ complex in the majority of wet ashing herb, spice and bean or wet digested rock samples without reducing agent. A comparison between present (average of three values) and published results ${ }^{[22]}$; that investigated the amount of iron in kakade (10.62 vs. $\left.6.57 \mathrm{mg} \mathrm{g}^{-1}\right)$ and black pepper $\left(8.32\right.$ vs. $\left.3.9 \mathrm{mg} \mathrm{g}^{-1}\right)$ is higher whereas anise (3.95 vs. $7.67 \mathrm{mg} \mathrm{g}^{-1}$ ) and cumin (7.75 vs.8.28 $\mathrm{mg} \mathrm{g}^{-1}$ ) is lower than in the published results. Higher concentration may be possibly attributed to contaminated samples, which comes from the irrigation with contaminated water and addition of fertilizer and/or herbicides to soil.

\section{CONCLUSION}

One of the most important aspects of the present work is the simple, rapid method for spectrophotometric determination of ferrous and ferric individually or a mixture of ferrous and ferric as $[\mathrm{Fe}$ $\left.\left(\mathrm{H}_{2} \text { dapd }\right)_{2}\right]^{2+}$ complex in acidic water-ethanol medium ( $\mathrm{pH}$ 2.5). $\mathrm{H}_{2}$ dapd reagent has the ability to react instantaneously with ferrous whereas ferric within a period of $4.0 \mathrm{hr}$. The sensitivity and selectivity of the method were improved with first derivative. Comparing the present procedure with the DCDT reagent before or after extraction into amyl alcohol concerning detection and tolerance limits for $\mathrm{Cu}^{2+}, \mathrm{Cr}^{3+}, \mathrm{Ni}^{2+}$ and $\mathrm{Co}^{2+}$ indicated that $\mathrm{H}_{2}$ dapd is sensitive and selective (except for $\mathrm{Cu}^{2+}$ ). On comparing one method with existing flow 
injection analysis methods, indicates that the use is readily available, relatively inexpensive apparatus and simplicity of the experimental conditions make the proposed method a good alternative for routine analysis. Recommended method is economical since it is cheaper than AAS and does not need any gas maintenance. The method has been successfully used for determining total iron directly in digesting foodstuffs, herbs, spices and rock solution as [Fe $\left.\left(\mathrm{H}_{2} \text { dapd }\right)_{2}\right]^{2+}$ in the absence of reducing agents.

\section{REFERENCES}

1. Hartley, F.R., C. Burgess and R.M. Alcock, 1980. Excerpted from the Book Solution Equilibria. Published by John Wiley and Sons, pp: 1-357.

2. Campanella, L., K. Pyrzynska and M. Trojanowicz, 1996. Chemical speciation by flow-injection analysis. A Review, Talanta, 43: 825-838.

3. Agrawal, Y.K., 1997. Extraction and determination of iron (II) by spectrophotometry and inductively coupled plasma, atomic-emission spectrophotometry, in pharmaceutical and environmental samples. Indian Drugs, 34: 269-274.

4. Fan, X.Z., C.H. Zhu and H.C. Liu, 1997. A study of the color reaction of a new thiazolylazo reagent 2-[2(6-methylbenzothiazolyl) azo] -5-diethylaminobenzoic acid with iron (II) and its application. Fenxi Shiyanshi, 16: 23-26.

5. He, Q.H., Y.Y. Zhu and X.Q. Mao, 1997. Study on the color reaction of iron (II) with 5-(3,5-dibromo2-pyridylazo) -2,4-diaminotoluene. Lihua Jianyan Huaxue Fence, 33: 268-270.

6. Oliveira, P.C.C. and J.C. Masini, 2001. Sequential injection determination of iron (II) in anti-anemic pharmaceutical formulations with spectrophotometric detection. Anal. Lett., 34: 389-397.

7. Liang, W.A., Z.Y. Zhang and S.F. Zou, 1997. Ultraviolet derivative spectro-photo-metric determination of trace iron with sulfosalicylic acid. Fenxi Kexue Xuebao, 13: 145-147.

8. Salinas, F., J.C.J. Sanchez and T.G. Diaz, 1986. Spectro-photo-metric determination of iron in wines, foods and mineral with 5,5-dimethyl-1,2,3Cyclo-hexanetrione 1,2-dioxide 3-thiosemicarbazone. Anal. Chem., 58: 824-827.

9. Gallego, J.M.L., T.G. Diaz and J.C.J. Sanchez, 1988. Spectro-photo-metric determination of iron in acids. Analyst, 113: 1341.
10. Salinas, F., T.G. Diaz and J.C.J. Sanchez, 1987. Spectrophotometric determination of iron by extraction of the iron (II) -5,5-dimethyl-1,2,3Cyclo-hexanetrione-1,2-dioxime-3-Thiosemicarbazone complex. Talanta, 34: 655-656.

11. Hanania, G.I.H. and D.H. Irvine and F. Shurayh, 1965. The effect of Coordination on ionization. Part III. Pyridine-2, 6-dialdooxime and its iron (II) complex. J. Chem. Soc., pp: 1149-1154.

12. Yatsimirsky, A.K., P. Gomez-Tagle, S. EscalanteTovar and L.R.R. Ramirez, 1998. Kinetics and mechanism of ester hydrolysis by metal complexes of 2,6-diacetylpyridine dioxin. Inorg. Chim. Acta, 273: 167-174.

13. Jencks, W.P., 1989. Excerpted from the Book Catalysis in chemistry and Enzymology Published by McGraw Hill New York.

14. Pruthi, J.S., 1980. Excerpted from the Book Spices and Condiments: Chemistry, Microbiology, Technology. Published by Academic Press Inc.

15. Allen, S.E., 1989. Excerpted from the Book Chemical Analysis of Ecological Material. Published by Black-Well Scientific, pp: 1-368.

16. Satake, M., N. Sugita and M. Katyal, 1990. Annali Di Chimica, 80: 385.

17. Komy, Z., E. Roekens and R. Van Grieken, 1988. Analysis of rain water by differential pulse stripping Voltammetry in nitric acid medium. Anal. Chim. Acta, 204: 179-187.

18. Mohan, M. and M. Kumar, 1985. Transition-metal chemistry of oxide-containing ligands-xxvii. Fiveand six-coordinate complexes of iron (II) and iron (III) with 2,6-diacetylpyridine dioxin. Tetrahedron, 4: 1929-1939.

19. Miller, J.N., 1991. Basic statistical methods for analytical chemistry part 2. Calibration and regression methods. Analyst, 116: 3-14.

20. Agnihotri, N.K., V.K. Singh and H.B. Singh, 1997. Derivative spectrophotometric determination of copper (II) in non-Ionic micellar medium. Talanta, 45: 331-341

21. Baucom, E.I. and R.S. Drago, 1971. J. Amer. Chem. Soc., 39: 469.

22. Abou-Arab, A.A.K. and M.A. Abou-Donia, 2002. Heavy metals in Egyptian spices, medicinal plants and the effect of processing on their levels. J. Agric. Food Chem., 48: 2300. 